\title{
PHARMACEUTICAL SCIENCES
}

DOI https://doi.org/10.30525/978-9934-26-038-4-51

\section{РОЗРОБКА СКЛАДУ ТА ТЕХНОЛОГІЇ КОСМЕТИЧНОГО ЗАСОБУ ДЕПІГМЕНТУЮЧОЇ ДІЇ}

\author{
Казакова В. С. \\ кандидат фармачевтичних наук, дочент, \\ доцент кафедри косметології і аромології \\ Начіональний фармацевтичний університет
}

Петровська Л. С.

кандидат фармачевтичних наук, дочент, доцент кафедри косметології і аромології Начіональний фармацевтичний університет

\author{
Черемісіна В. Ф. \\ кандидат медичних наук, доиент, \\ доиент кафедри косметології і аромології \\ Начіональний фармачевтичний університет \\ м. Харків, Украӥна
}

Гіперпігментація - одна 3 найбільш актуальних проблем сьогодення, не зважаючи на сучасний стрімкий розвиток медицини та косметології в цілому.

Пігментні плями можуть викликати дискомфорт у людей, особливо у жінок, і за статистикою, є однією із основних причин звернення до косметолога $[1$, с. 25]. У зв'язку з цим, розробка ефективних косметичних засобів депігментуючої дії $\epsilon$ актуальною задачею на сучасному косметичному ринку.

3 метою розробки рецептури та технології косметичного засобу депігментуючої дії було поставлене завдання - провести комплексні фізико-хімічні дослідження 3 метою вибору та обгрунтування оптимального складу та технології виготовлення крему-емульсії з вмістом альфа-гідроксикислот (АНА-кислот).

За результатами аналізу літературних джерел встановлено, що для корекції гіперпігментації використовують апаратні методики (ультраіонофорез, іонофорез, мікродермобразія, електропорація); мануальні методи (відбілюючі та освітлюючі маски, хімічні пілінги, ферментні пілінги тощо) [2, с. 63]. Також застосовується великий арсенал косметичних та лікарських косметичних препаратів, механізм дії яких базується на судинорозширювальному і місцево подразнюючому терапев- 
тичному ефекті, що покращує кровопостачання верхніх шарів шкіри i трофіку тканин. В депігментуючих косметичних засобах містяться речовини, які мають наступний механізм дії: пригнічують тирозинази, стимулюють перетворення кератиноцитів, гальмують дозрівання меланосом, окислюють і руйнують меланін тощо [3, с. 67]. Проведений аналіз косметичного ринку України встановив, що серед продукції, яка чинить депігментуючу дію, вітчизняних препаратів - 13\%, імпортна продукція складає 87\%. Серед товарного асортименту даного призначення присутні як косметичні, так і лікарські косметичні засоби [4, c. 47].

Таким чином, розробка нових вітчизняних косметичних засобів для забезпечення ефективного та доступного лікування пігментних плям у різних категорій населення $є$ актуальною задачею.

Для розробки складу косметичного засобу депігментуючої дії будо обрано такий тип дисперсної системи, як емульсія олія у воді. Кремоподібна форма випуску здатна забезпечувати заданий лікувальний та косметичний ефекти, оптимальну консистенцію, необхідну проникність засобу через шкірні покриви та споживчі характеристики [5, с. 386].

3 метою вибору складу основи та комплексу біологічно активних речовин зважали на клінічні прояви гіперпігментації зрілої шкіри та особливості косметологічного догляду за нею [6, с. 665]. За результатами дослідження фізико-хімічних показників модельних емульсій, у складі яких варіювали кількістю масляної фази, емульгаторів та їх співвідношенням, було обрано оптимальний склад масляної фази, яка $є$ складовою емульсійної основи косметичного засобу. Оптимальні характеристики встановлено для масляної фази у складі арганової та оливкової олій у співвідношенні 1:3. У якості емульгаторів було запропоновано використання суміші полісорбату-80 та гліцерил моностеарату. Також було досліджено доцільність введення комплексу активних інгредієнтів, а саме: АНА- кислот, екстракту солодки, екстракту огірка, алое вера, ефірної олії чайного дерева та ефірної олії лимону.

3 метою розробки технологічного процесу виготовлення косметичних емульсій досліджували наступні стадії:

1. Приготування водної фази ( змішування води очищеної та водорозчинних екстрактів).

2. Приготування масляної фази - (розплавлення воскоподібних складових із врахуванням температур плавлення інгредієнтів).

3. Гомогенізація фази і дисперсійного середовища;

4. Охолодження емульсії, введення термолабільних компонентів і додаткове диспергування;

5. Визрівання крему і фасування.

Враховуючи фізико-хімічні властивості складових крему, було запропоновано використовувати «гарячий/гарячий» метод отримання косметичної емульсії 
- Масляну фазу нагрівали до 54-64 $\mathrm{C}$ і об’єднували 3 водною фазою, нагрітої до такої ж температури.

- Суміш гомогенізували до досягнення ступеня дисперсності в середньому 1-2 мкм.

- Охолодження здійснювали при повільному перемішуванні до температури загусання системи - 40 - 42 градуси Цельсія.

- Після охолодження крему до 40-35 градусів Цельсія, вводили почергово, при періодичному перемішуванні, термолабільні активні інгредієнти крему.

- Перемішували крем до оптимального ступеня дисперсності, перевіряли відсутність розшарування системи, за допомогою рН-метра визначали водневий показник крему.

- Фасуємо та маркуємо готовий крем.

Оцінювали якість крему косметичного депігментуючої дії відповідно до вимог ДСТУ ISO / TR 18811: 2019 Косметика. Керівництво по визначенню стабільності косметичних продуктів (ISO/TR 18811:2018, IDT). Основні характеристики косметичного продукту засвідчили відповість вимогам стандарту.

Таким чином, за результатами проведеної роботи обрано та досліджено оптимальну основу для косметичного засобу депігментуючої дії; здійснено вибір біологічно активних речовин для крему косметичного депігментуючої дії та обгрунтовано доцільність їх використання у косметичному засобі; розроблено рецептуру крему косметичного депігментуючої дії з урахуванням фізико-хімічних властивостей активних та допоміжних речовин; розроблено технологію приготування крему косметичного депігментуючої дії та проведено оцінку його якості у відповідності до діючого стандарту.

Результати роботи можуть бути рекомендовані для подальшого дослідження безпечності та ефективності крему косметичного депігментуючої дії.

\section{Література:}

1. Богданова С. А., Копанева М. С. Коллоидно-химические свойства косметических средств с гидролатами. Вестник Казанского технологического университета. 2017. Т. 20. № 10. С. 25-29.

2. Задионченко Е. В., Мальцева П. О. Дисхромии кожи и методы их коррекции. Международный студенческий научный вестник. 2015. № 6. C. 63-68.

3. Сергеев Ю. Ю., Мордовцева В. В., Сергеев В. Ю. Меланома кожи в практике дерматолога. Фарматека. 2017. Т. 17. № 350. С. 67-73.

4. Казакова I.C., Лебединець В.О. Аналіз та визначення перспектив розвитку ринку лікарських косметичних косметичних засобів в Україні «Сочіальна фармачія в охороні здоров'я». 2020. Том 6. № 2. С. 44-60. 
5. Технологія косметичних засобів: підручник для студ. вищ. навч. закладів / О. Г. Башура [та ін.]; за ред. О. Г. Башури, О. І. Тихонова. Харків : НФаУ; Оригінал, 2017. 552 с.

6. Московченко О.Ю. Обоснование состава лечебно-профилактического средства для коррекции ксероза, вызванного возрастными изменениями кожи / О.Ю. Московченко, Т.Н. Ковалева. Сб. мат. научно-практ. конф. студ. и молодых ученых «Инновации в медицине и фармации». Минск, БГМУ, 2017. С. 665-668.

DOI https://doi.org/10.30525/978-9934-26-038-4-52

\title{
ВИВЧЕННЯ АНТИОКСИДАНТНОЇ ТА АНТИЦИТОЛІТИЧНОЇ АКТИВНОСТІ ЕКСТРАКТУ З ЛИСТЯ СЛИВИ ЗВИЧАЙНОЇ (PRUNUS DOMESTICA)
}

\author{
Кравченко В. М. \\ доктор біологічних наук, професор, \\ завідувачка кафедри біологічної хімії \\ Національний фармацевтичний університет
}

\begin{abstract}
Шовкова 3. В.
кандидат фармачевтичних наук,

доиент кафедри аналітичної хімії та аналітичної токсикології

Національний фармацевтичний університет
\end{abstract}

Сенюк I. В.

кандидат фармачевтичних наук,

дочент кафедри біологічної хімії

Національний фармащевтичний університет

\author{
Шовкова О. В. \\ кандидат фармацевтичних наук, \\ асистент кафедри біологічної хімії \\ Національний фармащевтичний університет \\ м. Харків, Украӥна
}

Однією $з$ актуальних проблем сучасної фармакологічної науки $є$ створення нових більш ефективних лікарських засобів для фармакокорекції захворювань гепатобіліарної системи. Ураження печінки $\epsilon$ широко розповсюдженою причиною захворюваності та смертності 